Maurer School of Law: Indiana University

Digital Repository @ Maurer Law

\title{
Forging Fiscal Reform: Constitutional Change, Public Policy, and the Creation of Administrative Capacity in Wisconsin, 1880-1920
}

Ajay K. Mehrotra

Indiana University Maurer School of Law, amehrotr@indiana.edu

Follow this and additional works at: https://www.repository.law.indiana.edu/facpub

Part of the Political History Commons, Public Affairs, Public Policy and Public Administration Commons, Taxation-Federal Commons, and the Taxation-State and Local Commons

\section{Recommended Citation}

Mehrotra, Ajay K., "Forging Fiscal Reform: Constitutional Change, Public Policy, and the Creation of Administrative Capacity in Wisconsin, 1880-1920" (2008). Articles by Maurer Faculty. 48.

https://www.repository.law.indiana.edu/facpub/48

This Article is brought to you for free and open access by the Faculty Scholarship at Digital Repository @ Maurer Law. It has been accepted for inclusion in Articles by Maurer Faculty by an authorized administrator of Digital Repository @ Maurer Law. For more information, please contact rvaughan@indiana.edu. 


\section{AJAY K. MEHROTRA}

\section{Forging Fiscal Reform: Constitutional Change, Public Policy, and the Creation of Administrative Capacity in Wisconsin, 1880-1920}

At the turn of the twentieth century, Wisconsin, like many northern industrial states, faced a profound fiscal challenge. As one concerned citizen succinctly explained, "The two great administrative problems before our people at this time are, first, the control of corporate wealth, and, second, the establishment of a rational system of taxation." ${ }^{1}$ The large-scale structural pressures created by the rise of corporate capitalism and the decline of an obsolete tax system forced all levels of government to reexamine the substance and administration of their fiscal policies. At the state and local level, many governments addressed the mismatch between the increasing demand for state services and the declining supply of revenue by turning to new levies and innovative forms of administration.

In confronting the impending fiscal dilemmas, Wisconsin was a leader in forging fiscal reforms. Political activists, lawmakers, and other government actors in the Badger State led a turn-of-the-century property tax revolt when they sought to replace the aging, locally administered general property tax with a graduated income tax managed by a centralized, administrative bureaucracy. After a long and arduous process, reformers

\footnotetext{
In addition to the Boston University/Cambridge University Political History Conference, earlier versions of this article were presented at the Policy History Conference and the Law \& Society Association's Annual Conference. For their comments and encouragement, I would like to thank the participants at those venues, and Mary Bilder, Kathy Conzen, Mary Dudziak, David Duff, Robin Einhorn, Dan Ernst, Mike Grossberg, Morton Keller, Mark Leff, Assaf Likhovski, Bill Novak, Dustin Plummer, Bruce Schulman, Chris Tomlins, and Julian Zelizer.
}

THE JOURNAL OF POLICY HISTORY, Vol. 20, No. 1, 2008.

Copyright (C) 2008 The Pennsylvania State University, University Park, PA. 
were able in 1911 to enact the first effective state-level income tax that would soon become the model for other states and even the national government. Although the income tax did not become a wholesale replacement for the general property tax, its limited success was achieved in part because tax reformers overcame numerous institutional barriers as they helped promote a more equitable and effective distribution of fiscal burdens. By confronting the entrenched power of political parties, state constitutional constraints, and cultural resistance to centralized authority, activists and politicians established an institutional beachhead for the subsequent development of a new fiscal order —one that was guided not simply by the need for greater revenue but by concerns for equity and economic and social justice.

Because the campaign to use progressive income taxes as a complete replacement for the property tax was ultimately unsuccessful, the turn-ofthe-century tax reform movement reveals both the limits and accomplishments of fiscal reform. The inability of Wisconsin's lawmakers to relinquish their reliance on the property tax was perhaps a missed opportunity during a unique period of political plasticity. But the income tax campaign did initiate the incremental process of diminishing Wisconsin's dependence on property taxes. Indeed, by the end of the 1920s, the income tax generated a significant portion of the state's revenues. Still, the income tax did not become the dominant source of subnational government revenue throughout the country, as some reformers had envisioned. Over time, as part of the institutional compromise of federalism, different levels of American governance divided the sources of tax revenue. By the end of the twentieth century, the federal government would come to control most income tax revenue, state governments would rely on a combination of sales and income taxes, and local governments would be left primarily with property taxes. ${ }^{2}$

Despite the limited success of the income tax, the early twentiethcentury tax reform campaign had a durable impact on the administration of public finance. Since the property tax was embedded in the nineteenthcentury state-level system of "courts and parties," activists seeking to make taxation more transparent, rational, routinized, and fair inevitably had to confront the local process of tax administration. ${ }^{3}$ In challenging the dominance of the locally administered property tax, reformers wrestled power away from local political parties and consolidated it in the hands of elite professional experts. They attempted, in the process, to alter the popular and cultural perception of local self-government, which at the time valorized local administration by party officials as an established part 
of the nation's republican traditions. This essay investigates how and why tax reformers in Wisconsin were able to help build the administrative capacity to levy new forms of taxation but were unable to replace the property tax with a progressive tax on income.

Other studies of state and local tax reform during the Gilded Age and Progressive Era have had little to say about the peculiar persistence of the property tax, and even less to say about Wisconsin's administrative achievements. Those scholars who have examined the political history of Wisconsin's tax reforms have generally elided the development of administrative capacity; instead, they have depicted the new tax laws and policies as the consequences of newly formed interest groups or coalitions that sought to recalibrate tax burdens by increasing taxes on corporations and wealthy individuals. ${ }^{4}$ By contrast, others have explained the emergence of the Wisconsin income tax as an apolitical solution to the technical problems posed by the dysfunctional property tax. ${ }^{5}$ Scholars who have explored state and local tax reforms more generally have frequently noted the persistence of the property tax, but given their broad comparative analysis they have not attempted to explain why particular tax policies within specific states crystallized or wasted away. ${ }^{6}$

In analyzing the qualified achievements of the Wisconsin income tax movement, this essay provides a glimpse at a larger narrative about the dramatic structural transformation in American public finance that occurred at the turn of the twentieth century. The tax reforms that were enacted in Wisconsin and other northern industrial states not only presaged changes at the national level; they also reflected a broader and more fundamental revolution in American state-society relations. Although graduated income taxes, both at the national and state level, had modest beginnings - with low marginal rates and high exemption levels affecting only the wealthiest of taxpayers - they were, as the legal historian Lawrence Friedman has noted, "the opening wedge for a major transformation of American society." By reallocating the burdens of financing a modern industrial democracy, this new form of fiscal governance was concerned with redefining the meaning of modern citizenship, facilitating a fundamental change in existing political arrangements, and underwriting the emergence of the modern American liberal state.

\section{The Roots of the Fiscal Challenges}

The fiscal challenges that Wisconsin and other states faced were rooted in a dual set of modern pressures. On one side, broad social 
dislocations wrought by the accelerating forces of industrialization, urbanization, and mass migration created an overwhelming demand for government goods and services. On the other side, the growing ineffectiveness of the property tax and the constitutional limits on government debt constrained the supply of public funds. Together, these twin forces compelled policymakers in Wisconsin and many other states to confront the increasing importance of public finance. While some sought to limit the increasing size of state governments, many others attacked the anachronistic property tax and searched for alternative forms of financing.

Scholars have long noted how demographic pressures became more pronounced in the United States during the late nineteenth and early twentieth centuries. ${ }^{8}$ Wisconsin was representative of this trend. Between 1880 and 1920, its population doubled; the annual value of the state's total manufactured products increased fourteenfold; and its leading city, Milwaukee, jumped from the nineteenth to the twelfth largest in the nation. ${ }^{9}$ Although local governments, which had greater flexibility in using debt, accounted for most infrastructure investments, the state's spending on social programs increased at a steady pace along with such accelerated growth. ${ }^{10}$ In the last decades of the nineteenth century, Wisconsin's expenditures on education and charitable and penal institutions grew dramatically. Per capita spending on education alone nearly doubled from 1880 to $1900 .{ }^{11}$ Spending on institutions for dependents gave way to public goods such as roads and highways in the early twentieth century, but the overall demand for public resources continued unabated. ${ }^{12}$

While increased spending exerted demand-side pressures on Wisconsin's treasury, the state also faced a shrinking supply of public funds. Like most other northern industrial states, Wisconsin relied heavily on the general property tax for state and local revenue. ${ }^{13}$ The general property tax was meant to apply equally to real and personal property, to tangible as well as intangible forms of wealth. The owners of land, buildings, machinery, and other forms of real property were to be treated the same as those who held their wealth in personal property such as stocks and bonds, or income from professional salaries and fees. ${ }^{14}$

With the rise of finance capitalism and the growing prevalence of corporate securities, however, personal property became increasingly intangible and more difficult to assess. Moreover, professional salaries became more common and conspicuous. ${ }^{15}$ Consequently, tax experts throughout the country proclaimed that the property tax discriminated against the poor, particularly farmers, whose limited holdings were corporeal and in plain sight. The urban rich and affluent, by contrast, 
held much of their wealth in the form of cash salaries or intangible personal property like securities, mortgages, and other financial assets, which often escaped assessment. "The omission of this kind of property from assessment," the Wisconsin tax commission proclaimed in 1898, "is perhaps the most noticeable of all defects in the administration of our tax laws." ${ }^{16}$ Other tax experts concurred. As Edwin R. A. Seligman, a leading tax expert, noted in 1890 , the general property tax "pressed hardest on those least able to pay." 17

Even before lawmakers and policy analysts took up the calls for an income tax, citizens throughout the state acknowledged how the existing property tax implicated regional and class differences. Wealthy urban citizens and affluent farmers, who were often noninstitutional holders of mortgages—or what were referred to as "credits" at the time-were able to shift their fair share of financing the public sector. As the Milwaukee state senator F. W. von Cotzhausen observed, "Large fortunes, invested in credits and securities, escape taxation altogether because not visible or tangible, thus throwing increased burden upon others." ${ }^{18}$ Reformers in other states like Minnesota attempted to address the taxation of intangibles by lowering the rates on such property, but the limited success of taxing classified property at different rates and constitutional restrictions requiring uniformity of rates seemed to deter Wisconsin tax experts. ${ }^{19}$

The inherent defects of a tax on personal property may have appeared obvious. But for many reformers the greater deficiency was the assessment process. In most states, locally elected or appointed, part-time assessors calculated and collected the general property tax. Charged with the responsibility of collecting the levy from their neighbors, local assessors had neither the expertise nor the gumption to determine accurately the value of personal intangible property such as stocks, bonds, mortgages, and other financial assets. Furthermore, as officials beholden to the authority of local political parties, assessors were exposed to the disciplining efforts of party bosses. ${ }^{20}$ Even though Wisconsin, following the lead of Indiana and other states, had shifted the assessment process from local to county boards as early as 1868, the lack of a professionally trained group of supervisors seemed only to exacerbate the political nature of the tax. Not only did county boards regularly overassess the forest lands of nonresidents, but they also allegedly shifted property tax liabilities from town to town depending upon the ethnic composition of the different municipalities. "Under a purely local system of administration," the Harvard economist Charles J. Bullock explained, "there never was and never will be a generally satisfactory assessment of either income or property." 21 
For many tax experts, the political nature of property tax assessments, and not the self-interest of taxpayers, created a culture of deceit. "The American taxpayer is the most maligned creature in all the annals of fiction," proclaimed T. S. Adams, a University of Wisconsin political economist and a member of the state tax commission. "He has been compared, confused and used synonymously with the liar. As a matter of fact, when confronted with an equitable tax and a fearless assessor, he is amazingly honest," wrote Adams. "It is the locally elected property assessor, bent on conciliating voters and on keeping his own underpaid job, who has demoralized the American property tax and made it in the past a by word for chicanery, inefficiency and inequality." 22

It was not only the power of local politics that embedded the property tax in the nineteenth-century system of state and local public finance. Just as the federal courts complemented the power and policies of nineteenth-century national political parties, state courts and constitutions provided similar support at the subnational level. The state constitutional clauses that required "uniform" property taxes and limited a state's debt obligations were meant initially to be checks on the power of state legislatures, and as ersatz proxies for equal taxation. ${ }^{23}$ But over time, as the inadequacies of the property tax and the increased demand for public goods and services strained government resources, these constitutional provisions became institutional obstacles for those lawmakers and reformers seeking to redistribute fiscal burdens and change the structure and activities of state and local governments. ${ }^{24}$

Wisconsin's constitutional uniformity clause, which was adopted in 1848, was a pithy one sentence: "The rule of taxation shall be uniform and taxes shall be levied upon such property as the legislature shall prescribe." ${ }^{25}$ Yet, this language, as interpreted by the Wisconsin courts, did not provide much relief from the arbitrary and capricious application of politically motivated property tax assessments. In principle, the Wisconsin Supreme Court did intervene to prevent "errors of judgment and mistakes of fact" made by local assessors, but as long as such errors were "exceptional and happen in good faith, not affecting the principle or the general equality of the assessment," they were deemed constitutional. Indeed, only the most overt and egregious types of malfeasance compelled the court to strike down an assessment process; for example, when all the lands in a particularly diverse township were assessed at precisely the same value. ${ }^{26}$

The state constitution and the court's rulings compounded the institutional obstacles that stood before reformers. As a result, state and 
local governments were being squeezed from all sides. An increased demand for public services, a declining tax base, and a dysfunctional and legally entrenched system of tax assessment all posed serious fiscal challenges, forcing lawmakers and activists to search for alternative means of financing.

\section{The Constitutional Campaign for an Income Tax}

If broad structural forces were the fundamental driving force behind the creation of the first workable state income tax, the triggering event for the new law seemed to be the Panic of 1893. The ensuing economic slump of the 1890s led to the formation of a unique political coalition that challenged the conservative core of Wisconsin's Republican Party. The fiscal dilemma and the economic depression, as David Thelen has shown, united "workers and businessmen, foreign born and native born, Populist and Republicans, drinkers and abstainers, Catholics and Protestants" behind a whole host of political, social, and economic reforms, including tax reform, which "was the most popular and powerful of the state's reform movements." The emergence of this diverse group of engaged citizens came at a time when political arrangements throughout the nation were changing dramatically, as a more fragmented, issuefocused form of politics began to eclipse the traditional power of political parties. $^{27}$

Although it would be several years before the state constitution was amended to allow for a graduated income tax, the incremental process of tax reform began toward the end of the depression, when the legislature created a temporary tax commission in 1897. Kossuth K. Kennan, a Milwaukee railroad lawyer, had long advocated the need for a state tax commission to rationalize the various state and local tax laws. As one of the members of the first temporary tax commission, Kennan helped identify the myriad problems that plagued the property tax. He and his colleagues also made several recommendations addressing the assessment process, including a proposal for placing the supervision of tax administration in the control of objective, nonelected, professional experts. ${ }^{28}$

A graduated income tax was not among the first tax commission's recommendations in 1898. But four years later, after the election of Governor Robert La Follette Sr., the first permanent tax commission led the charge for an income tax as a method to combat the vexing problem of taxing intangible personal property and professional salaries. One of the 
leading supporters for an income tax within La Follette's progressive Republican wing was Nils P. Haugen, a lawyer and former U.S. congressman, who became one of the first members of the permanent tax commission. Known as La Follette's "first lieutenant," Haugen represented the Norwegian base of La Follette's progressive coalition. ${ }^{29}$ Working closely with Haugen was T. S. Adams, the University of Wisconsin political economist who would go on to become a leading, internationally known tax expert. The Haugen-Adams collaborative relationship reflected the unique institutional links that existed in Madison between the state legislature and the flagship university campus, a link that explained why Wisconsin was one of the nation's leading laboratories of democratic reforms. Contemporaries described this distinctive reciprocal relationship as the "Wisconsin Idea"-the belief that social scientific knowledge ought to be used to solve the problems and improve the lives of the community's citizens. ${ }^{30}$

Together with Adams and others, Haugen spearheaded the campaign for a state income tax as a solution to the inequities of the property tax. As a lawyer, Haugen understood that if the income tax was to become a serious replacement for the property tax, the proper constitutional foundations needed to be established. While tax reformers at the national level were contemplating a constitutional amendment to secure a federal income tax, Wisconsin's political activists had already begun the process of changing their state constitution to permit progressive income taxes. By mobilizing those most disgruntled with the property tax, especially among his own agrarian constituency, Haugen was able to compel the state legislature in 1903 to consider a constitutional amendment permitting state income taxation. Approved as part of a larger tax overhaul, which included the adoption of a graduated inheritance tax and modifications to the system of corporate taxes, the amendment called for a simple addition to the uniformity clause permitting progressive income taxes. ${ }^{31}$ It read: "Taxes may also be imposed on incomes, privileges and occupations, which taxes may be graduated and progressive, and reasonable exemptions may be provided." 32 After some initial technical setbacks, the income tax amendment was overwhelmingly approved in a 1908 statewide referendum by a margin of 2 to $1 .^{33}$

Wisconsin's pioneering role in tax reform came at the height of the social and political fervor of the Progressive Era. The income tax was thus part of a broader movement for democratic reforms that included direct primary elections, the referendum and initiative, and protective labor legislation and conservation laws. Many of these reforms required 
constitutional changes. With the approval of consecutive progressive governors, lawmakers and citizens in the early decades of the century frequently amended the Wisconsin constitution. Between 1910 and 1930, the state constitution was amended fifteen times during each decade, far more than in previous or subsequent decades. These numerous modifications illustrated how legislators and citizens during these years viewed the constitution not simply as a rigid restraint on state action, but rather as a flexible democratic institution reflecting changing political and social values. ${ }^{34}$

\section{Building Administrative Capacity}

Despite the straightforward success of the income tax amendment, reformers and policy experts acknowledged that amending the constitution was only the beginning of the struggle for a graduated income tax. Politicians like Haugen and tax experts like Adams soon realized that an income tax could become reality only if the machinery of tax administration itself underwent a type of constitutional change. Income would be no easier to assess than intangible personal property, and thus as long as the assessment and supervision process was left in the hands of local political officials there was little hope of effectively raising revenue in an equitable manner with an income tax. Activists therefore advocated the centralization of tax assessment at the state rather than the county level. In what was perhaps the boldest of reforms, they sought to remove tax administration from the ambit of local political machines and place that responsibility onto the state's growing cadre of bureaucratic experts.

The creation of a centrally administered income tax was not simply a technical issue for many reformers; it implicated broader concerns about the democratic roots and consequences of tax reform. During the legislative hearings discussing the first income tax law, Adams explained how the prevailing ineffective property tax system eroded public confidence and trust in democratic institutions, and hence adversely affected the state treasury as well as the larger body politic. "The statute under which taxation is now carried on is really class legislation, molded in favor of the possessors of intangible property," Adams declared. "The smaller property-owners bear the whole burden." With this discrepancy in place "the tax system is founded on evasion, undervaluation, and perjury." Responding to charges that graduated income taxes were a form of "creeping socialism," Adams informed lawmakers that the inefficacy of 
the property tax system created an environment that compelled citizens to question their faith in democratic institutions. "We are all engaged in the scramble," Adams charged. "Democracy is failing in one of the most important phases of government-that of collecting the necessary revenues in an equitable manner. It might be termed a great conspiracy, in which democracy corrupts its citizens and, in turn, is corrupted." Seen in this light, the move to a centrally administered income tax, Adams concluded, was not a socialist measure, but rather an "ultraconservative" return to the roots of American democracy. ${ }^{35}$

Adams's earlier defense of the honest American taxpayer together with his support for the centralization of bureaucratic control was indeed a strange mix of faith in democratic participation and expert administration. Using centralized, bureaucratic administration to defend the honesty and civic values of the quotidian taxpayer was an unusual rhetorical move, but one that resonated with the times. Progressivism itself seemed to contain this, and other, seemingly inherent tensions between democratic decisionmaking and expert management. ${ }^{36}$

Some tax experts, like Adams, sincerely—perhaps even naivelybelieved that solving the administrative problems of the tax assessment process was more than half the battle; that once thoroughgoing civilservice reforms had been implemented, and politics had been divorced from the assessment process, the bureaucratic autonomy would exist to allow the state income tax to replace the property tax. ${ }^{37}$ Neither Adams nor Haugen, however, mentioned that the administrative reforms they proposed necessarily meant that a great deal of political and economic power would also be bestowed upon the state tax commission, on which they both served. For Adams the social scientist, the fortification of fiscal power was an inexorable function of centralization; for Haugen, it was a political opportunity to protect the interests of his own constituency. The latter fact did not escape the legislators who opposed the income tax.

\section{Overcoming Popular Resistance to Centralized Authority}

In building the necessary administrative capacity, reformers also faced popular resistance to the consolidation of bureaucratic authority. The traditional American political and legal culture of self-governance and communal sovereignty played a key role in framing the debates surrounding administrative tax reform. Haugen, in particular, ran across this type of resistance with many of his constituents. In an extended correspondence 
with H. S. Wilson, the president of the State Normal School in River Falls, Haugen expressed his views on the local control of tax assessments. Over time, Haugen had persuaded Wilson that income was theoretically the proper measure of taxation, and that any new state levy could benefit localities through intergovernmental transfers. Nevertheless, Wilson continued to resist any administrative tax reforms. "I am not yet ready to turn over local taxation with all of its glaring evils to some centralized authority," wrote Wilson in the summer of 1910. "This is not in harmony with the American Spirit." 38

In response, Haugen acknowledged that "the sentiment in favor of what Americans believe is local self-government is the greatest objection that we have to meet in order to improve our taxation system." But what Americans' believed to be self-government was, in Haugen's estimation, completely illusory. "There is absolutely no choice in an American town, city or village as to the kind of government under which the local community desires to live," wrote Haugen. "The jacket is cut and fitted by central authority and the local community must wear it no matter how great the misfit may be." Those who held on to the outdated nineteenthcentury notion of local self-government amid the dramatic changes of twentieth-century industrial capitalism, Haugen argued, undermined rather than enforced the rule of law. ${ }^{39}$

What Haugen feared even more than the deterioration of law, however, was the notion of American exceptionalism that undergirded the unyielding support for local self-government reflected in Wilson's letters. Wilson's invocation of the "American Spirit" was merely representative of a much broader concern among provincial officials over the loss of local control, and thus Haugen felt compelled to correct this misconception. Using Germany as a comparative example, Haugen provided Wilson with a detailed quantitative analysis of how German public finance was, in fact, saturated with local self-government. From this Haugen concluded that "the local self-government which we enjoy is the privilege of ignoring the law-setting it aside-and leaving the offender to go unpunished or unrebuked." If this is what Wilson meant by self-government, Haugen sardonically remarked, "there is probably less self-government in Germany than in the United States." 40

In challenging the traditional reliance on local authority, reformers like Haugen were also using tax policy to forge a new and broader sense of citizenship. Even though local governments were still the source of most public spending, Haugen believed that, in an increasingly interdependent social world, individual citizens needed to recognize that they 
had obligations and responsibilities that stretched beyond their local communities to the larger realm of state government. Frontier residents during the antebellum era could perhaps express their allegiance to local institutions through the "civic grammar" and "fiscal syntax" of navigating complex local taxes, ${ }^{41}$ but in a modern urban-industrial age citizens need to view their responsibilities and obligations more broadly. Fostering the legitimacy of a state-level income tax, along with the centralization of fiscal administration, was an important step in forging this new civic identity. In coming years, the federal constitutional amendment permitting progressive income taxes and the subsequent federal tax laws would replicate this process of reconfiguring citizenship on a national scale.

\section{The 1911 Income Tax and a Constitutional Challenge}

As Haugen was attempting to convince Wisconsinites like Wilson of the virtues of a centrally administered income tax, the legislature was drafting the details of the new statute. Although Haugen and Adams were early proponents of the income tax, by 1911 they had been displaced in the legislative drafting process by two other experts: the economist $\mathrm{D}$. O. Kinsman and Charles McCarthy, the head of the state legislative reference library and the fountainhead of many of Wisconsin's progressive reforms. During the legislative discussions over the bill, commercial interests opposed an income tax, particularly one levied on corporate income. ${ }^{42}$ McCarthy appeared to be unconcerned with the arguments that a corporate income tax might adversely affect Wisconsin's economic prospects by driving capital investments to neighboring states. By contrast, Adams and other tax experts seemed to believe that the spread of state income taxes was inevitable, and that any short-term comparative disadvantage that Wisconsin faced in attracting capital would soon be mitigated in the long run when other states followed its lead. ${ }^{43}$

The concern over corporate income taxes in a federalist system was not the only issue that divided McCarthy from other supporters of the income tax. Unlike Adams and Haugen, who believed that a graduated income tax could be a wholesale replacement for the property tax, McCarthy and Kinsman maintained that because of revenue concerns the state could not repeal the taxation of real property. If tax reform was necessary to provide increased revenue for the growing social-welfare state, eliminating all property taxes appeared to be too risky. McCarthy proposed that the new income tax simply replace the personal property component of the general property tax. ${ }^{44}$ 
The final version of the 1911 income tax reflected McCarthy's vision. With the support of Milwaukee's Socialists, the enacted law had a graduated rate structure that began at 1 percent for all incomes over $\$ 1,000$ and reached a maximum rate of 6 percent for incomes greater than $\$ 12,000$, ensuring that the levy would solely affect the state's wealthiest citizens. But more important, the income tax effectively replaced only the taxation of personal property, leaving the levy on real property intact. It did so by eliminating several types of intangible personal property such as stocks and bonds from the tax rolls, and by permitting taxpayers an "offset," or credit, against their income tax liability for any taxes paid on the remaining forms of taxable personal property. Although lawmakers-fearful of losing too much revenuedid not agree with the Adams and Haugen proposal to have the income tax replace the entire property tax, they did adopt the administrative changes that Adams and Haugen recommended. Indeed, nearly twothirds of the statute was dedicated to administrative changes. The new law centralized the assessment process, taking it away from local officials and placing it in the hands of professional experts supervised by the state tax commission. These professionals were chosen not because of any political associations but rather by their performance on rigorous civil service exams, which tested financial and tax expertise. Even skeptical political economists, who believed a federal income tax was more feasible than a state levy, viewed the new Wisconsin law as "a revolution in administrative methods." 45

Reflecting on the early success of the new income tax, Wisconsin reformers noted that one of the main reasons for the achievement was the accompanying civil services reforms and the method of collecting tax information at the source. "The greatest discovery of the Wisconsin income tax is the non-political assessor of incomes," Adams declared. This ensured that the tax system contained a "set of officers not dependent for the retention of their offices upon the favor of the people whom they assess." For Adams, such administrative reform marked a historical moment in the development of American taxation. "The appointment of a body of protected tax officials marks a new epoch in the fiscal history of the state of Wisconsin, possibly in that of the United States," Adams concluded. "It is very largely their work that has made the income tax a success." The efficiency of income tax collections was facilitated further by the tax commission's subsequent adoption of regulations that required parties paying salaries, dividends, and interest to provide the tax commission with information about the taxpayers receiving such income. ${ }^{46}$ 
This crude form of withholding underscored the importance of third-party reporting for a quasi-voluntary system of tax compliance. With these administrative changes, the Wisconsin income tax law became an effective source of revenue, and soon became the model for several other states, and the federal government when it enacted the first permanent national income tax in 1913. Adams carried the message of administrative reform with him to Washington when he became an adviser to the U.S. Treasury Department during World War I. ${ }^{47}$

Before Wisconsin could become a model for others, however, the courts had to rule on the constitutionality of the new income tax statute. Just months after it was enacted, lawyers for a Wisconsin realtor contended that numerous provisions of the new law, including the consolidation of administrative powers, violated the state constitution. While the Wisconsin Supreme Court made quick work of this challenge, its reasoning and dicta illustrated how the judiciary during this period was willing to go beyond its traditional role of policing the boundaries between permissible public and private action. Instead, the court took this opportunity to explicate the democratic roots and comparative context of the income tax. ${ }^{48}$

In a unanimous decision upholding the statute, the court stated that the substance of the new law signaled "a very important change in the general taxation policy of the state." The enactment of the 1911 law, coming on the heels of the 1908 state constitutional amendment, reflected the popular support behind progressive income taxes. The new law, wrote Chief Justice John B. Winslow on behalf of the court, "is but the concrete embodiment of a popular sentiment which has been abroad for some time." More specifically, the court noted that the 1908 constitutional amendment had explicitly paved the way for the graduated income tax. This "change was ratified by the people at the general election held in November 1908," wrote Winslow, "and thus was clearly expressed by both the legislature and the people the idea that some form of general taxation in addition to or in place of property taxation might well be adopted." 49

As part of his general defense of the law, Winslow also noted the successful comparative history of the income tax. Echoing comments made by Governor Francis McGovern when he signed the bill, ${ }^{50}$ the court confidently claimed that "the income tax is no new and untried experiment in the field of taxation." Identifying the venerable tradition of income taxes in "many of the civilized governments of the world" and among "twenty of our own states," as well as "for a brief period by the government of the 
United States," the court concluded that "taxation should logically be imposed according to ability to pay, rather than upon the mere possession of property, which for various reasons may produce no revenue to the owner." Thus, in passing the new law, Winslow contended that "the legislature is only adopting a scheme of taxation which has been approved for many years by many of the most enlightened governments of the world, and has the sanction of many thoughtful economists." 51 The court's specific references to the use of income taxes in "civilized" communities and "enlightened governments" demonstrated how Wisconsin lawmakers in the early twentieth century were cognizant of the broader global context in which they operated. By creating a workable state income tax, they believed that they were helping lead their state, and their nation, out of its backward and uncivilized era and into a new period of economic and political development.

If tax reformers found some comfort in the court's ruling on the substance of the income tax, they were especially reassured by the judicial evaluation of the administrative modifications. Pointing to particular constitutional provisions that governed the election and appointment of local officials, the taxpayers/plaintiffs claimed that the newly created state powers of assessment violated "the constitutional guaranties of local self-government." In response, the court held that "the office of assessors of income," created by the new law, was neither a "county, city, town, or village" office, nor was it an office "existing in substance at the time of the adoption of the constitution, or essential to the existence or efficiency of either of said municipal divisions of the state." The court concluded instead that the centralized administration of assessments was "an entirely new office . . . whose election or appointment may be provided for in any way that the legislature may in its discretion direct." 52 Many observers, including the staunchly anti-income tax Milwaukee Sentinel, viewed the court's deference to the legislature as the death knell for the inchoate movement to repeal the income tax. ${ }^{53}$

\section{Conclusion}

Within a decade of its initial enactment, the Wisconsin income tax had achieved some important, albeit limited, success. Although it did not completely eclipse the property tax as the state's main source of revenue, it did begin the incremental process of diminishing the reliance on an obsolete system of taxing personal property. Perhaps more important, the 
administrative reforms enacted as part of the 1911 income tax law dramatically changed the way Wisconsin managed the assessment and collection of taxes. A process traditionally controlled by local politics gradually came under the domain of a relatively autonomous group of bureaucratic experts who could rely on an early form of information withholding to secure tax revenues. The building of administrative capacity was thus a critical step in addressing the fiscal challenges of the time, in forging a new form of citizen identity, and in laying the foundation for the subsequent growth of the public sector.

Despite the overwhelming skepticism of many tax experts, reformers in the Badger State were able to respond to the turn-of-the-century fiscal challenges by overcoming the political, social, and institutional resistance to reform. New political ideas and institutions thus mediated the broader socioeconomic forces driving fiscal change. Although its achievement may have precluded other, more radical fiscal reforms, the early success of the income tax emboldened other activists and politicians at the state and national level to pursue a similar set of fiscal changes. Indeed, reformers throughout the country understood that modernizing the prevailing system of taxation implicated broader transformations. Amending constitutions, creating administrative capacity, and overcoming popular cultural resistance to centralized authority were all necessary steps in the process of building a new fiscal order.

Indiana University, Bloomington

\section{Notes}

1. H. S. Wilson to Nils P. Haugen, 1 September 1910, Box 56, Nils P. Haugen Papers, The State Historical Society of Wisconsin, Madison (SHSW).

2. Biennial Report of the Secretary of State of the State of Wisconsin, 1927-1928 (Madison, 1928); Historical Statistics of the United States, Earliest Times to the Present, ed. Susan B. Carter et al. (New York, 2006), table Ea132-59, table Ea247-75, table Ea489-518.

3. Stephen Skowronek, Building a New American State: The Expansion of National Administrative Capacities, 1877-1920 (New York, 1982); Clifton K. Yearley, The Money Machines: The Breakdown and Reform of Government and Party Finance in the North, 1860-1920 (Albany, N.Y., 1970).

4. W. Elliot Brownlee, Progressivism and Economic Growth: The Wisconsin Income Tax, 1911-1929 (Port Washington, N.Y., 1975); John D. Buenker, The History of Wisconsin, Vol. IV, The Progressive Era, 1893-1914 (Madison, 1998); Robert C. Nesbit, Wisconsin: A History (Madison, 1973); David P. Thelen, The New Citizenship: Origins of Progressivism in Wisconsin, 1885-1900 (Columbia, Mo., 1972).

5. John O. Stark, "The Establishment of Wisconsin's Income Tax," Wisconsin Magazine of History (Autumn 1987): 27-45; Stark, A History of the Property Tax and 
Property Tax Relief in Wisconsin (Madison, 1992); Joseph A. Ranney, "Law and the Progressive Era, Part 2: The Transformation of Wisconsin's Tax System, 1887-1925," Wisconsin Lawyer 67 (August 1994): 22-25, 62-63.

6. R. Rudy Higgens-Evenson, The Price of Progress: Public Services, Taxation, and the American Corporate State, 1877-1929 (Baltimore, 2003); Morton Keller, Regulating a New Economy: Public Policy and Economic Change in America, 1900-1933 (Cambridge, Mass., 1990); Jon C. Teaford, The Rise of the States: Evolution of American State Government (Baltimore, 2002); John Joseph Wallis, "American Government Finance in the Long Run: 1790-1990," Journal of Economic Perspectives 14 (Winter 2000): 61-82; Yearley, The Money Machines. On the importance of slavery to the early development of the American property tax, see Robin L. Einhorn, American Taxation/American Slavery (Chicago, 2006).

7. Lawrence Friedman, History of American Law (New York, 1974), 497. See also Harry N. Scheiber, "The Road to Munn: Eminent Domain and the Concept of Public Purpose in the State Courts," Perspectives in American History 5 (1971): 400; James T. Kloppenberg, Uncertain Victory: Social Democracy and Progressivism in European and American Thought, 1870-1920 (New York, 1986), 355.

8. Robert H. Wiebe, The Search for Order, 1877-1920 (New York, 1967); Samuel P. Hays, The Response to Industrialism, 1885-1914 (Chicago, 1957); Louis Galambos, "The Emerging Organizational Synthesis in Modern American History," Business History Review 44 (1970): 279-90.

9. U.S. Bureau of the Census, Report on the Manufacturers of the United States at the Tenth Census, 1880 (Washington, D.C., 1991), 189, table IV; Statistical Abstract of the U.S., 1921 (Washington, D.C., 1922), 253, table 161; Campbell Gibson, Population of the 100 Largest Cities and Other Urban Places in the United States (Washington, D.C., 1998), 37, 41, tables 11, 19.

10. Wallis, "American Government Finance," 69-71; Thelen, New Citizenship, 30-31; Brownlee, Progressivism and Economic Growth, 45.

11. Higgens-Evenson, Price of Progress, chap. 2. In real terms, Wisconsin spent approximately $\$ 1.34$ per capita on common school spending in 1880 and $\$ 2.62$ by 1900 . Ibid., 28, table 1.

12. Transportation spending in Wisconsin, which was nearly nonexistent in 1910, had jumped to nearly 25 percent of total annual expenditures by 1920 . Higgens-Evenson, Price of Progress, fig. 5, appendix.

13. Estimates suggest that by 1902 property taxes accounted for 57 percent of all state government revenues, and roughly 73 percent of all local revenues. Wallis, "American government Finance," 70.

14. Title XIII, chap. 48, sections 1034, 1036, 1052, Supplement to the Wisconsin Statutes of 1898 (Chicago, 1906).

15. Alfred D. Chandler Jr., The Visible Hand: The Managerial Revolution in American Business (Cambridge, Mass., 1977); William G. Roy, Socializing Capital: The Rise of the Large Industrial Corporation in America (Princeton, 1997).

16. Wisconsin Tax Commission, Report of the Wisconsin State Tax Commission (Madison, 1898), 109-10. The Wisconsin Commission also "found frequent instances of an almost open and avowed practice of favoring particular interests and industries or classes of property." Ibid., 78.

17. Seligman, "The General Property Tax," Political Science Quarterly 5, no. 1 (1890): 62.

18. F. W. von Cotzhausen, "A Graduated Income Tax," Milwaukee Sentinel, 17 October 1904; in 1873, von Cotzhausen, as state senator, was one of the first government officials to call for tax reform. Emanuel L. Philipp, Political Reform in Wisconsin: A Historical Review of the Subjects of Primary Election, Taxation, and Railway Regulation (Milwaukee, 1910), 107. 
19. Charles J. Bullock, "The State Income Tax and the Classified Property Tax," in Proceedings of the Tenth Annual Conference under the Auspices of the National Tax Association (New Haven, 1917), 369; Teaford, Rise of the States, 47-49.

20. Yearley, The Money Machines, xii-xv; Higgens-Evenson, Price of Progress, 13-14; Teaford, Rise of the States, 45-46.

21. Stark, History of the Property Tax, 8; Bullock, "State Income Tax and Classified Property Tax," 375; Teaford, Rise of the States, 46.

22. T. S. Adams, "The Significance of the Wisconsin Income Tax," Political Science Quarterly 28 (December 1913): 569-85, at 575.

23. Glenn Fisher, The Worst Tax? A History of the Property Tax in America (Lawrence, Kans., 1996), chap. 4; Einhorn, American Taxation/American Slavery, 204.

24. Gail Radford, "From Municipal Socialism to Public Authorities: Institutional Factors in the Shaping of American Public Enterprise," Journal of American History 90, no. 3 (2003): 863-90.

25. Wisconsin Constitution, Section 1, Article VIII.

26. Marsh v. Supervisors 42 Wis. 502 (1877); see also Hersey v. Board of Supervisors, 37 Wis. 75 (1875); Bradley v. Lincoln County, 60 Wis. 71 (1884).

27. Thelen, New Citizenship, 204-7, 288; Richard L. McCormick, "The Party Period and Public Policy: An Exploratory Hypothesis," Journal of American History 66 (1979): 279-98; Michael McGerr, The Decline of Popular Politics: The American North, 1865-1928 (New York, 1986). For an updated reassessment of the party period, see Richard John, "Farewell to the 'Party Period': Political Economy in Nineteenth-Century America," Journal of Policy History 16, no. 2 (2004): 117-25.

28. Philipp, Political Reform in Wisconsin, 109-11; Kossuth Kent Kennan, "The Wisconsin Income Tax," Quarterly Journal of Economics 26, no. 1 (November 1911): 169-78; Wisconsin State Tax Commission, 1898 Report.

29. Nils P. Haugen, Pioneer and Political Reminiscences (Evansville, Wis., 1930); Robert La Follette to Nils Haugen, 24 September 1911; Haugen to La Follette, 2 November 1911, Box 56, Haugen Papers, SHSW; Brownlee, Progressivism and Economic Growth, 49-51; Buenker, History of Wisconsin, 442-43; Stuart D. Brandes, "Nils P. Haugen and the Wisconsin Progressive Movement" (Master's thesis, University of Wisconsin, 1965).

30. Charles McCarthy, The Wisconsin Idea (New York, 1912); Buenker, History of Wisconsin, 573-77.

31. Fredrick C. Howe, Wisconsin, An Experiment in Democracy (New York, 1912), 133-39; Philipp, Political Reform in Wisconsin.

32. Wisconsin Constitution, Section 1, Article VIII.

33. T. S. Adams, "The Wisconsin Income Tax," American Economic Review 1 (December 1911): 906-9, at 906. The amendment carried every county but one, and was ratified by a vote of 85,696 to 37,729 in November 1908 (ibid.).

34. Buenker, History of Wisconsin, 488-89; Jack Stark, The Wisconsin State Constitution: A Reference Guide (Westport, Conn., 1997), 8.

35. "Praise Income Tax," Milwaukee Journal, 24 May 1911; "Income Tax Hearing," (Milwaukee) Evening Wisconsin, 24 May 1911.

36. Wiebe, Search for Order; Eldon J. Eisenach, The Lost Promise of Progressivism (Lawrence, Kans., 1994); Daniel T. Rodgers, "In Search of Progressivism," Reviews in American History 10 (December 1982): 113-32.

37. In this sense, the tax experts employed by state tax commissions were similar to the "mezzo-level" actors of national executive agencies. On the importance of mezzolevel administrators, see Daniel P. Carpenter, The Forging of Bureaucratic Autonomy: Reputations, Networks, and Policy Innovations in Executive Agencies, 1862-1928 (Princeton, 2001), 18-25.

38. H. S. Wilson to Haugen, 24 July 1910, Box 56, Haugen Papers, SHSW. 
39. Haugen to Wilson, 26 July 1910, Box 56, Haugen Papers, SHSW; "Income Tax in Place of Personal Property Tax," Milwaukee Free Press, 26 May 1910.

40. Haugen to Wilson, 26 July 1910, SHSW; Haugen, Pioneer and Political Reminiscences, 158-59. On the transatlantic roots of American economic ideas during this period, see Daniel T. Rodgers, Atlantic Crossings: Social Politics in a Progressive Age (Cambridge, Mass., 1998), chap. 3.

41. Merle Curti, The Making of an American Community: A Case Study of Democracy in a Frontier County (Stanford, 1959), 270.

42. Not all businesses opposed the income tax. Some saw it as an opportunity to apply the efficiency of the business corporation to state and local governance. HiggensEvenson, Price of Progress.

43. Brownlee, Progressivism and Economic Growth, chap. 3; Buenker, History of Wisconsin, 551-54; Stark, "Establishment of Wisconsin's Income Tax."

44. Ibid. Adams to Haugen, 24 December 1910; Adams to Haugen, 1 April 1910, Box 56, Haugen Papers, SHSW; "Genesis of Wisconsin's Income Tax: An Interview with D. O. Kinsman," Wisconsin Magazine of History, September 1937, 4.

45. Wisconsin Session Laws (1911), Section 1087m-8(1) and (2), Chapter 658; Kennan, "The Wisconsin Income Tax," Quarterly Journal of Economics (1911); Seligman, The Income Tax, 421; J. C. Stamp, "The Tax Experiment in Wisconsin," Economic Journal 23, no. 89 (March 1913): 142-46.

46. T. S. Adams, "The Significance of the Wisconsin Income Tax," 572; Kossuth Kent Kennan, "The Wisconsin Income Tax," Annals of the American Academy of Political and Social Science 58 (March 1915): 65-76; Thomas E. Lyons, "The Wisconsin Income Tax," Annals of the American Academy of Political and Social Science 58 (March 1915): $77-86$.

47. Brownlee, Progressivism and Economic Growth, 49-50; Buenker, The History of Wisconsin, 554; James K. Conant, Wisconsin Politics and Government: America's Laboratory of Democracy (Lincoln, Neb., 2006), 298; Clara Penniman, State Income Taxation (Baltimore, 1980), table I, 2-3;

48. State ex rel. Bolens v. Frear; Winding v. Frear. The Court consolidated these two cases as the Income Tax Cases, 148 Wis. 456 (1911). "Believes Income Tax Law Invalid," Milwaukee Sentinel, 16 November 1911; "Income Tax Law Is Argued" Milwaukee Free Press, 21 November 1911.

49. Income Tax Cases, 504.

50. In signing the bill, Governor McGovern attached a lengthy memo that stated in part that "the plan of adjusting public burdens according to ability has been in successful operation for many years in Switzerland, Austria, France, England, Norway, Sweden, Denmark, Holland, and the German states." "Governor Calls Income Tax Just," Milwaukee Sentinel, 14 July 1911.

51. Income Tax Cases, 505.

52. Ibid., 511.

53. "Income Tax Law Valid, Says Court" Milwaukee Sentinel, 10 January 1912; "Hold's State's Taxation Plan Revolutionized," Milwaukee Free Press, 10 January 1912. 